\title{
Alum Catalyzed Simple and Efficient Synthesis of Bis(indolyl)methanes by Ultrasound Approach
}

\author{
Swapnil S. Sonar, Sandip A. Sadaphal, Amol H. Kategaonkar, Rajlumar U. Pokalwar, \\ Bapurao B. Shingate, and Murlidhar S. Shingare*
}

\author{
Department of Chemistrv. Dr. Babasaheb Ambedkar Marathwada Chiversin, Aurangabad-431004, M. S. India \\ ${ }^{*}$ E-mail: prof msshingare arediffmail.com \\ Recewed Februarv 12, 2009, Accepted Februarv 17. 2009
}

\begin{abstract}
Alum $\left.\left(\mathrm{KAl}_{(} \mathrm{SO}_{4}\right)_{2} \cdot 12 \mathrm{H}_{2} \mathrm{O}\right)$ is an inexpensive, efficient, non-toxic and mild catalyst for the synthesis of bis (indolyl)methanes by the reaction of $1 \mathrm{H}$-indole with various aldehydes/ketones under the influence of ultrasound irradiation in solvent-free condition. The remarkable advantages of this method are the simple experimental procedures, shorter reaction times, high vields of product and green aspects by avoiding toxic catalysts and solvents.
\end{abstract}

Key Words: Bis(indolyl)methanes. Alum. $1 H$-indole. Aldehydes/ketones. Ultrasound irradiation

\section{Introduction}

Indole and its derivatives are known as an important class of heterocyclic compounds in the pharmaceutical as well as synthetic chemistry. The most ubiquitous of the known bioactive alkaloids are based on the indole moiety. ${ }^{2}$ Medicinal chemists repeatedly turn to indole based compounds as a target pharmacophore for the development of therapentic agents. ${ }^{3}$ Bis(indolyl)alkanes have attracted considerable attention due to its diverse pharmacological and biological importance. The bioactive substrate including bis(indolyl)alkanes moiety are widely occurs in various natural products isolated from marine sponge alkaloids. ${ }^{4}$ Also. it shows potent antibacterial activity. ${ }^{5}$ In particular, bis(indolyl)methanes are the most active cniciferous substances for promoting beneficial estrogen metabolism and including apoptosis in human cancer cells.

Numerous methods have been reported for the synthesis of bis(indolyl)methanes using variety of reagents such as. $\mathrm{AcOH},{ }^{*} \mathrm{InCl}_{3}, \mathrm{LiClO}_{4}{ }^{*} \mathrm{NBS} . " \mathrm{PPh}_{3} \mathrm{HClO}_{4}$ " $\mathrm{NaHSO}_{4}$.

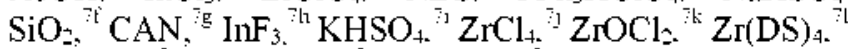
$\mathrm{P}_{2} \mathrm{O}_{5} / \mathrm{SiO}_{2}{ }^{* 110} \mathrm{Sb}_{2}\left(\mathrm{SO}_{4}\right)_{3}{ }^{\text {in }} \mathrm{PPh}_{3} \mathrm{CCl} .{ }^{\circ}$ A part from this. synthesis of bis(indolyl)methanes also have been achieved using Zeolites. ${ }^{8}$ Clays. $^{9}$ ionic liquids. ${ }^{161}$ metal triflates. ${ }^{11}$ ion exchange resin ${ }^{12}$ and rare earth metal. ${ }^{13}$

At present, with the raid development in the fields of synthetic and catalytic chemistry. researchers have started to develop environmentally benign processes to avoid or minimize the harmful effects. The application of solvent-free reaction conditions in organic chemistry has been explored extensively within the last decade. It has been demonstrated to be an efficient technique for various organic reactions. Solvent-free conditions often lead to a remarkable decrease in reaction time. increased yields. easier workup. enhancement of regio and stereo selectivity of reaction matches with the green chemistry protocol. ${ }^{14}$

Ultrasound irradiation has been established as an important technique in synthetic organic chemistry. It has been used as an efficient heating source for the organic reactions. Shorter reaction time is the main advantage of ultrasound-assisted reactions. Simple experimental procedure, very high yields, increased selectivities and clean reaction of many ultrasound induced organic transformations offers additional convenience in the field of synthetic organic chemistry. ${ }^{15}$

Alum $\left(\mathrm{KAl}\left(\mathrm{SO}_{4}\right)_{2} \cdot 12 \mathrm{H}_{2} \mathrm{O}\right)$ were found to be effective in the synthesis of cis-isoquinolic acids. ${ }^{160}$ mono- and disubstituted 2.3-dihy'droquinazolin- $4(1 H)$-ones. ${ }^{160}$ dihydropyrimidines via Biginelli reaction. ${ }^{160}$ coumarins. ${ }^{16 \mathrm{~d}} 1,3,4$-oxadiazoles. ${ }^{\text {loe }}$ dibenzoxanthenes. ${ }^{165} 1.5$-benzodiazepines. ${ }^{168}$ trisubstituted imidazoles $^{1 \text { th }} 2$-arylbenzothiazoles and 2-arylbenzoxazoles. ${ }^{16 i}$ However. there are no any reports of the use of alum as a catalyst for the synthesis of bis(indolyl)methanes.

\section{Experimental}

Bandelin Sonorex $(35 \mathrm{kHz})$ ultrasonic bath was used for ultrasonic irradiation. ${ }^{1} \mathrm{H}$ NMR spectra were recorded on Mercury Plus Varian in $\mathrm{CDCl}_{3}$ at $400 \mathrm{MHz}$ using TMS as an internal standard. IR spectra were recorded on a Perkin-Elmer FTIR using $\mathrm{KBr}$ discs. Mass spectra were recorded on Micromass Quattro II using electrospray Ionization technique. showing $(\mathrm{m}+\mathrm{l})$ peak as a base peak. The progress of the reactions was monitored by TLC.

\section{General Procedure}

A nuixture of $1 H$-indole ( $5 \mathrm{mmol}$ ). aldelyde ( $2.5 \mathrm{mmol}$ ) and powdered alum ( $10 \mathrm{~mol} \%$ ) was irradiated under ultrasound irradiation at ambient temperature for appropriate time (Table 4). The progress of reaction was monitored by TLC. After the completion of reaction $20 \mathrm{~mL}$ ice cold water was added to the reaction mixture. The solid obtained was filtered and recrystallized from ethanol to get the pure product.

\section{Result and Discussion}

In continuation of our interest in synthesis of bis(indolyl)methanes ${ }^{1, i, 1}$ and the development of novel synthetic metho- 
<smiles>c1ccc2[nH]ccc2c1</smiles>

1<smiles>[R]C([R])=O</smiles>

2a-1

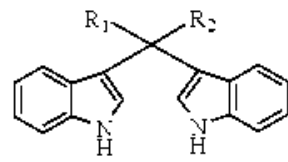

3a-1

\section{Scheme 1}

dologies $^{16 i, 17}$ herein. we would like to report a simple, efficient and rapid method for the synthesis of bis(indolyl)methanes (Scheme 1). It was found that alum is an effective promoter in the synthesis of bis(indolyl)methanes by the reaction of $1 H$-indole with aryl and heteroaryl aldehydes under ultrasound irradiation.

In order to get the best experimental reaction condition. the reaction of $1 H$-indole 1 and benzaldehyde 2 a (in 2:1 molar ratio) in the presence of $20 \mathrm{~mol} \%$ of alum under solvent-free condition has been considered as a standard model reaction. We have investigated the model reaction by grinding at ambient temperature. $60{ }^{\circ} \mathrm{C}$ or $100^{\circ} \mathrm{C}$ and by ultrasound irradiation method. When the reaction was carried out by grinding method the product obtained in low yield (Table 1 . Entry 1). In the next step. we carried out the reaction at $60^{\circ} \mathrm{C}$ and $100^{\circ} \mathrm{C}$ which provided the product in almost similar yields after $60 \mathrm{~min}$ (Tablel. Entry 2-3). However. the best result was obtained by ultrasound irradiation at ambient temperature and the product was obtained within $10 \mathrm{~min}$ in $92 \%$ yield (Table 1 , Entry 4 ).

To determine the appropriate concentration of the catalyst alum. we investigated the model reaction at different concentrations of catalyst like $2.5 .5,7.5,10$ and $12.5 \mathrm{~mol} \%$ under ultrasound irradiation. The product formed in 74. 80. 85, 92 and $92 \%$ yield respectively. This indicates that $10 \mathrm{~mol} \%$ of alum is sufficient for the best result (Table 2. Entry 4).

To establish the generality with respect to the carbonyl compounds: $1 H$-indole were treated with various aldehydes

Table 1. Effect of Cataly sts on the synthesis of Bis(indolyl)methanes $3 a^{a}$

\begin{tabular}{cccc}
\hline Entry & Condition & Time (min) & Yield $^{b}(\%)$ \\
\hline 1 & Grinding/tt & 60 & 14 \\
2 & $60^{\circ} \mathrm{C}$ & 60 & 71 \\
3 & $100^{\circ} \mathrm{C}$ & 60 & 73 \\
4 & Ultrasound/rt & 10 & 92 \\
\hline
\end{tabular}

${ }^{a} \mathbf{1}(5 \mathrm{mmol}) .2 \mathrm{a}(2.5 \mathrm{mmol})$ alum $\left(20 \mathrm{~mol}^{0} \mathrm{i}\right) .{ }^{k}$ Isolated yields.

Table 2. Effect of Concentrations of Alum for synthesis of Bis(indolyl)methanes $\mathbf{3} \mathrm{a}^{a}$

\begin{tabular}{cccc}
\hline Entry & Alun $(\mathrm{mol} \%)$ & Time (min) & Yield $^{b}(\%)$ \\
\hline 1 & 2.5 & 10 & 74 \\
2 & 5 & 10 & 80 \\
3 & 7.5 & 10 & 85 \\
4 & 10 & 10 & 92 \\
5 & 12.5 & 10 & 92 \\
\hline
\end{tabular}

1 ( 5 mol), 2 a ( 2.5 mmol), under the influence of ultrasound irradiation. "Isolated yields. and ketones in the presence of alum under the influence of ultrasound irradiation. It was observed that aryl aldehydes were reacted faster (5-15 min) and providing excellent yields $85-95 \%$ (Table 3, Entry 1-10). In case of $\alpha-\beta$ unsaturated

Table 3. Synthesis of Bis( indolyl methanes $3 a^{a}$

\begin{tabular}{|c|c|c|c|c|c|c|}
\hline \multirow{2}{*}{ Entry } & \multirow{2}{*}{$\begin{array}{l}\text { Com- } \\
\text { pound }\end{array}$} & \multirow{2}{*}{ Aldehyde/Ketone } & \multirow{2}{*}{$\begin{array}{l}\text { Time } \\
\text { (min) }\end{array}$} & \multirow{2}{*}{$\begin{array}{c}\text { Yield }^{b} \\
(\%)\end{array}$} & \multicolumn{2}{|c|}{ M.P. $\left({ }^{\circ} \mathrm{C}\right)^{6}$} \\
\hline & & & & & Found & Lit \\
\hline 1 & $\mathbf{3 a}$ & & 10 & 92 & $121-123$ & $123-125$ \\
\hline 2 & $3 b$ & & 10 & 87 & $95-97$ & $96-98$ \\
\hline 3 & $3 c$ & & 12 & 87 & $191-193$ & $190-192$ \\
\hline 4 & $3 d$ & & 15 & 85 & $221-222$ & $220-222$ \\
\hline 5 & $3 e$ & & 15 & 84 & $111-112$ & $111-112$ \\
\hline 6 & $3 f$ & & 12 & 87 & $125-126$ & $124-125$ \\
\hline 7 & $3 g$ & & 15 & 86 & $100-101$ & $100-102$ \\
\hline 8 & $3 h$ & & 7 & 92 & $77-78$ & $76-77$ \\
\hline 9 & $3 \mathbf{i}$ & & 10 & 92 & $75-76$ & $74-76$ \\
\hline 10 & $3 \mathbf{j}$ & & 5 & 95 & $222-223$ & $221-223$ \\
\hline 11 & $3 k$ & & 15 & 83 & $100-102$ & $100-102$ \\
\hline 12 & 31 & & 17 & 88 & $138-140$ & $137-139$ \\
\hline 13 & $3 m$ & & 20 & 88 & $277-279$ & $278-280$ \\
\hline 14 & $3 n$ & & 20 & 90 & $321-322$ & $320-323$ \\
\hline 15 & 30 & & 30 & 53 & $190-191$ & $189-190$ \\
\hline 16 & $3 p$ & & 30 & 42 & $120-121$ & $118-120$ \\
\hline
\end{tabular}

1 $15 \mathrm{mmol})$. 2a $(2.5 \mathrm{mmol})$, alum $\left(20 \mathrm{~mol}^{0} \cdot 0\right)$ under ultrasound irradiation. "Isolated vields. "All the melting points were matched with the reported data. 
Table 4. Comparison of result with reported procedure for synthesis of Bis indolyl)methanes $3 a^{a}$

\begin{tabular}{|c|c|c|c|c|c|}
\hline Entry & Catalyst & Catalyst (mol\%) & Solvent/Medilum & Time $(\min )$ & Yield $(\%)$ \\
\hline l & $\operatorname{Ln}(\mathrm{OTf})_{3}$ & 10 & $\mathrm{EtOH} \mathrm{H}_{2} \mathrm{O}$ & $12 \mathrm{~h}$ & $95^{11 \cdot 2}$ \\
\hline 2 & $\mathrm{LiClO}_{+}$ & 10 & $\mathrm{CH}_{3} \mathrm{CN}$ & $5 \mathrm{hl}$ & $90^{78}$ \\
\hline 3 & $\mathrm{Sb}_{2}\left(\mathrm{SO}_{4}\right)_{3}$ & 5 & $\mathrm{CH}_{3} \mathrm{OH}$ & 90 & $96^{711}$ \\
\hline 4 & Dy $(O T)_{3}$ & 2 & Ionic liquid & 60 & $98^{16}$ \\
\hline 5 & HY-Zeolite & $0.2 \mathrm{~g}$ & $\mathrm{CH}_{2} \mathrm{Cl}_{2}$ & 60 & $85^{8 \pi}$ \\
\hline 6 & $\mathrm{ZrCl}_{4}$ & 1 & $\mathrm{CH}_{3} \mathrm{CN}$ & 35 & $91^{7 j}$ \\
\hline 7 & $\mathrm{ZTOCl}=$ & l & $\mathrm{CH}_{3} \mathrm{CN}$ & 35 & $89^{7 \mathrm{k}}$ \\
\hline 8 & $\mathrm{La}(\mathrm{PFO})_{3}$ & 5 & $\mathrm{EtOH}$ & 30 & $90^{13}$ \\
\hline 9 & $\operatorname{In}\left(\mathrm{OTf}_{2}\right)_{2}$ & 5 & $\mathrm{CH}_{3} \mathrm{CN}$ & 25 & $71^{1 \mathrm{th}}$ \\
\hline 10 & $\mathrm{Zr}(\mathrm{DS})_{+}$ & 10 & $\mathrm{H}_{2} \mathrm{O}$ & 25 & $94^{[1]}$ \\
\hline 11 & Alum & 10 & - & 10 & 92 \\
\hline
\end{tabular}

1 was treated with $\mathbf{2 a}$. Isolated yields.

aldehy'de the product formed in $83 \%$ yield. (Table 3 . Entry 11). In comparison with these results. heteroaryl aldehydes forms their respective bis(indolyl)methanes in longer times (17-20 min) with 88-90\% yields (Table 3. Entry 12-14). Unfortunately ketones were afforded the desired product in lower yield (Table 3. Entry 15-16).

Various substituted aryl aldehydes were used for the sy'nthesis of bis(indolyl)methanes having different substituents such as $-\mathrm{Cl},-\mathrm{OH}$. $-\mathrm{NO}_{3}$. $-\mathrm{Me}$. -OMe. It was found that: electron donating substituent requires longer time where as electron withdrawing substituent requires shorter time for the completion of reaction (Table 3. Entry 4 and 8 ).

With these optimized reaction conditions: we have carried out the reaction of $1 H$-indole (1) with various aryl or heteroaryl aldelydes/ketones $(\mathbf{2} \mathbf{a}-\mathbf{l})$ in the presence of alum ( $10 \mathrm{~mol} \%$ ) under the influence of ultrasound irradiation at ambient temperature. The corresponding bis(indolyl)methanes (3a-l) were formed within short reaction times in excellent yields and confirmed by IR. ${ }^{1} \mathrm{H}$ NMR, Mass spectroscopic analy sis. ${ }^{18}$ The results are summarized in Table 3 .

In order to show the merit of alum in comparison with other catalysts used for the similar reaction. we have tabulated some of the results in Table 4 . As it is evidence from the results. alum found to be effective catalyst for the synthesis of bis(indolỵl)methanes.

\section{Conclusion}

In conclusion. alum is an easily available, inexpensive. efficient and safe catalyst for the synthesis of bis(indolyl)methane derivatives from various aryl or heteroaryl aldelydes by ultrasound irradiation. The remarkable advantages offered by this method are simple experimental procedure, solventfree reaction conditions. short reaction times, high yields, and easiness of product isolations.

Acknowledgments. The authors are thankful to the Head. Department of Chemistry, Dr. Babasaheb Ambedkar Marathwada University, Alurangabad-431 004. MS. India for providing the laboratory facilițr.

\section{References and Notes}

1. Sundberg, R. T. In The Chemistry of Indoles: Academic Press: New York, 1996: p 113.

2. Sniechus, V. In The Alkaloids; Academic Press: New York, 1968: Vol. 11.p 1.

3. Gribble, G. W. In Comprehensive Heterocyclic Chemistry, $2^{\text {nd }}$ ed.: Pergamom Press: New York, 1996; Vol. 2, p 211

4. (a) Morris, S. A.; Anderson, R. T. Tetwhedron 1990, 46, 715. (b) Bifulco, G.: Bruno, I.: Riccio, R.; Lavayre, J.: Bourdy, G. J. Nat. Prod 1995, 58, 1254 (c) Miyake, F. Y.: Yakushijin, K.: Horne, D. A. Org. Letr. 2002, 1,941. (d) Tiang, B.; Yang, C. G.: Wang, J. J. J. Org. Chem. $2002,67,1389$.

5. Hong, $\mathrm{C}$; Firestone, G. L: Bjeldanes, L. F. Biochent. Phamacol. 2002, 63, 1085

6. Ge, X.: Yannai, S.: Rennert, G.: Gruener, N.; Fares, F. A. Biochem. Biophys. Res. Commthn. 1996, 228, 153.

7. (a) Kamal, A.; Qureshi, A. A. Tetrohedron 1963, 19, 513. (b) Babu, G.: Sridhar, N.; Perumal, P. T. Symth Commun. 2000, 30 , 1609. (c) Yades, J. S.; Reddy, B. V. S.; Murthy, V. S. R.: Kumar, G. M.; Madan, C. Snthesis 2001, 783. (d) Koshima, H.; Matsuaka, W. J. Heterocklic Chent. 2002, 39, 1089. (e) Nagarajan, R.: Perumal, P. T. Sinth. Commm 2002,32, 105 . (f) Ramesh, C.; Baneriee, I.; Pal, R.; Das, B. Adv. Sinth. Catal. 2003, 345, 557. (g) Ramesh, C.: Ravindranath, N.: Das, B. $J$. Chem. Res. Smop. 2003, 72. (h) Bandgar, B. P.; Shaikh, K. A. J. Chem. Res. Synop. 2004, 34. (i) Nagarajan, R.; Perumal, P. T. Chem. Lett. 2004, 33, 288. (i) Nagawade, R. R.; Shide, D. B. Bull. Korean Chem. Soc. 2005, 26, 12. (k) Nagawade, R. R.; Shinde, D. B. Acta Chin. Slov, 2006, 53, 210 . (1) Zolfigol, M. A.; Salehi, P; Shiri, M: Tarkouchian, Z. Catal. Commtun. 2007, 8 , 173l. (m) Hasaninejad, A.; Zare, A.; Sharghi, H.; Niknam, K: Shekouhya, M. Hwivoc 2007, xin, 39. (n) Srinivasa, A.; Varma, P. P: Hulikal, V. Monat Fur Chente. 2008, 139, 111. (o) Nezhad, A. K.; Parhami, A.; Zare, A.; Zare, A. R. M.; Hasaninejad, A.; Panahi, F. Swhthesis 2008, 617.

8. (a) Reddy, A. V.: Ravinder, R.; Reddy, V. L. N.: Goud, T. V.; Ravikanth, V.: Venkateseswarlu, Y. Synth. Commm 2003, 33 , 3687. (b) Karthik, M:- Tripathi, A. K.; Gupta, N. M.; Palanichamy, M: Murugesan, V. Catal Conmmo 2004, 5, 371.

9. (a) Chakrabarty, M.: Gosh, N.: Basak, R.: Harigaya, Y. Tetrahedron Lett. 2002, 43, 4075. (b) Pnieres-Carrillo, G.; Garcia-Estrada, J. G.: Gutierrez-Ramirez, J. L.; Alvarez-Toledano, C. Gren Chemt 2003, 5,337.

10. (a) Yaday, I. S.: Reddy, B. V. S.; Sunitha, S. Adv. Swth Catal. 2003, 3+5, 349. (b) Ii, S. T.; Zhou, M. F.: Gu, D. G.; Wang, S. Y:; Loh, T. P. Sinten 2003, 2077. (c) Ji, S. J.; Zhou, M. F.; Gu, D. G.; 
Jiang, Z. Q.: Loh, T. P. Eur, J. Org. Chem, 2004, 1584, (d) Sadaphal, S. A.; Sonar, S. S.; Shingare, M. S. Central Euro. J. (Them. 2008, 6, 622.

11. (a) Chen, D; Yu, L.; Wang, P. G. Tetrahedron Lett. 1996, 37 , 4467. (b) Nagarajan. R. Perumal. P. T. Tetwhedron 2002, 58 , 1229. (c) Mi, X. L.: Luo, S. Z; He, J. Q:; Cheng, J. P. Tetrahedron Lett. 2004, $45,4567$.

12. Feng, X. L.; Guan, C. J.; Zhao, C. X. Synth. Comnnw 2004, 34, 487

13. Wang, L. M.; Han, T. W.; Tian, H.; Sheng, J.: Fan, Z. Y.: Tang, X. P. Svmlett 2005, 337

14. Tanaka, K. F. Chen. Rev. 2000, 100, 1025.

15. (a) Mason, T. T.: Lorimer, J. P. In Sonochentstry: Theory, Application and Uses of Lltrasomd in Chemistry, Tohn Wiley and Son: New York, 1988. (b) Suslick, K. S. In Cltrasonnd, its Chemical. Physical and Biological Effects: VCH: Weinheim, 1988. (c) Gaplovsky, A: Gaplovskv; M: Toma, S.; Luche, J. L. J. Org. Chem. 2000, 65, 84t4. (d) Deshmukh, R. R.; Rajagopal, R.: Srinivasan. K. V. Chem. Commum. 2001, 1544.

16. (a) Azizian, J.: Mohamnnadi, A. A.; Karimi, A. R:; Mohannnadizadeh, M. R. J. Org. Chem. 2005, 70, 350. (b) Dabiri, M.; Salehi, P; Otokesh, S.; Baghbanzadeh, M.; Kozehgary, G.; Mohammadi, A. A. Tetrahedron Lett. 2005, 46, 6123. (c)
Azizian, I: Mohammadi, A. A.: Karimi, A. R.; Mohammadizadeh, M. R. Applied Catalysis 2006, 300,85. (d) Dabiri, M.; Baghbanzadeh. M.: Kiani. S: Vakilzadeh. Y. Monatshefte Fur Chiente 2007, 138, 997. (e) Dabiri, M:- Salehi, P: Baghbartzadeh, M:- Bahramnejad. M. Wonatsheffe Fur Chieme, 2007, 138. 1253. (f) Dabin, M.; Baghbanzadeh, M:; Nikcheh, M. S.; Arzroomchilar, E. Bioorg. Med. Chem. Lett. 008, 18, 436. (g) Mahajan, D.; Nagvi, T.; Sharma, R. L.; Kapoor, K. K. Austrolian J. Chem 2008, 61, 159 (h) Mohammadi, A. A.; Mivechi, M:; Kefayati, H. Monatshefte Fw Chieme 2008, 139,935. (i) Pawar, S. S.; Dekhane, D. V.; Shingare, M. S.; Thore, S. N. Australian J. Chem. 2008, 61,905.

17. (a) Hangarge, R. V.; Sonwanle, S. A.; Jarikote, D. V.; Shingare, M. S. Gieen Chem 2001, 3, 310 (b) Hangarge, R. V.: Tarikote, D. V.: Shingare, M. S. Green Chem. 2002, 4, 266. (c) Madje. B. R.: Patil, P. T.; Shindalkar, S. S.: Benjamin, S. B.: Dongare, M. K.: Shingare, M. S. Catalvis Contmin. 2004, 5, 353. (d) Pawar, S. S.; Dekhane, D. V.; Shingare, M. S.; Thore, S. N. Tetrahedron Left. 2008, 49, 4252. (e) Pawar, S. S.: Uppalla, L. S.: Shingare, M. S.: Thore. S. N. Tenahedron Lett. 2008. 19.5858.

18. $3,3^{\circ}$-Bis (indolyl) phenylmethane (3a): $\mathrm{IR}\left(\mathrm{KBr}, \mathrm{cm}^{-1}\right)$ : 3478,1601 , 1522. ${ }^{1} \mathrm{H}$ NMR (CDCl $\left.400 \mathrm{MHz}\right)$ o $5.89(1 \mathrm{H}, \mathrm{s}) 6.67(2 \mathrm{H}, \mathrm{s})$, $7.09-7.58(1.3 \mathrm{H}, \mathrm{m}), 7.94(2 \mathrm{H}, \mathrm{bs}, \mathrm{NH})$. ES-MS: $m z 322(\mathrm{M}+1)$. 